workers' point of view, with the 'ego-ideal'. This would explain to some extent three contradictory attitudes towards the upper class-the attitude of wanting to rebel against it, the attitude of wanting to attain it, and the attitude of wanting to submit to it. On the other hand, pure class-consciousness in the Marxist sense stresses only companionship in a continuation of the sibling relationship, the 'id'. But we also need the child-adult (parent) relationship, the 'super-ego'. Now all revolutions towards one class lead to dictatorships, and these are thereby socially unstable. A revolutionary movement can scarcely be as morally satisfying as a 'patriotic' movement.

Summing up, Prof. Ginsberg said that he felt the Marxist point of view, which he by no means wholly accepts, had been rather underestimated in discussion and that there are aspects of it which still throw light on present conditions. There is a certain reality in 'class', in so far as 'you feel at home' with somebody of your own class. There is much else that can be said; what is needed now is more thoughtful study.

\section{ANIMAL HUSBANDRY IN INDIA*}

\author{
By SIR ARTHUR OLVER, C.B., C.M.G. \\ Royal (Dick) Veterinary College, Edinburgh
}

$I^{\mathrm{T}}$ would be quite impossible to gain a clear idea of the complexity of the problems facing animal husbandry in India without some understanding of the special factors conditioning the subject in India. For example : (1) Religious and traditional prejudices and customs. (2) Effect of the density of the population and the low purchasing power of the cultivators on farming practice. (3) General lack of appreciation of the fundamental principles which underlie proper breoding, feeding and management, and the great need which exists for a properly balanced system of land utilization. (4) Lack in most Provinces and Dtates of any expert animal husbandry organization devoted solely to the interests of livestock. (5) Annual droving of millions of dealers' cattle from north to wuth of India.

Slaughter. The cow is a semi-sacred animal and must not be slaughtered. In strict Hindu communities, it is not permissible to give a merciful release even to a fatally injured and suffering animal. These inhibitions are productive of the most far. reaching difficulties and make it impracticable to carry on dairying or stock breeding on strictly commercial lines.

Castration. Until comparatively recently, stock owners were unwilling to castrate their cattle at an early age, though the males and females run together on village grazing grounds. This objection is now being overcome, and castration of inferior animals is carried out on a large scale by Provincial veterinary departments. It cannot, however, be too much or too often emphasized that no lasting progress can be expected in livestock improvement until arrangements are made for controlled mating, and for the proper feeding and management of breeding females and young stock.

Grazing areas. Though highly desirable, the im. provement of such grazing areas as remain is not a solution of the cattle-feeding problem. The best of these areas tend to be taken up for cultivation, and

- Substance of a lecture before the India and Burma Section of the Royal Society of Arts, delivered on March 13. in any event, cultivators ought to aim at devoting a portion of their holdings to fodder crop production ; thereby producing better stock and more milk, and helping to maintain the fertility and physical condition of the soil. Without such a change of system -where necessary-progressive degeneration of cattle seems eertain to follow the gradual disappearance of good grazing lands on which the better cattle are at present bred.

Pinjrapoles and Gaushalas. The semi-religious pinjrapoles and gaushalas which are maintained in most cities throughout India have in many cases become anything but the homes of rest and comfort for derelict animals they are intended to be. By arranging for competent management and by breeding from the best of the cows and selling their milk, it has been shown that conditions can be greatly improved and profits made. Further, by taking up land for cultivation outside the city, the extra funds thus obtained can be utilized, to great advantage, to provide fodder crops and grazing for the hopelessly derelict and for the better feeding of the milking herd and young stock. By using selected sires, valuable young bulls were also produced, which should be of considerable value to breeders in the vicinity. These institutions could thus be made valuable demonstration centres all over India, and in addition to their great educational value, would save large numbers of quite good milch cows which are com. mitted to their care.

Density of population. Owing to the smallness of the holdings and the low purchasing power of the individual, it has generally been considered imprac. ticable for the Indian ryot to produce fodder crops for the proper feeding of his cattle, or to produce or purchase the increased supplies of milk which are essential for the health and proper development of the people. The tendency has been to consider that the only practicable policy is to produce more and more crops for sale or direct human consumption. As a result, soil fertility and humus content have been greatly depleted in many areas and enormous damage is being done by denudation, owing to removal of cover and humus from the soil. There seems, however, to be no reason why, by a suitable system of mixed farming, the ryots in suitable areas should not obtain as great money returns as under the present system of devoting their entire holdings to crops and, in addition, better stock and an invaluable supply of milk and dairy products for their families. Experiments undertaken to test this view have in fact shown that by substituting mixed farming, including milk production, for the mere raising of crops for sale, agriculture in many parts of India could be raised to a higher level.

Dung burning and the manurial value of livestock. Throughout the drier parts of India the custom of burning cow dung for fuel is a serious handicap to agriculture. A great deal of manurial value is lost ; the soil is deprived of humus; and, as cattle are not usually herded on the land due for cultivation, the manurial value of their urine is also lost.

Moreover, under the present system, village grazing grounds become so trodden and infected with disease that it is impossible to breed or maintain any but the most stunted stock on them.

In the absence of available firewood, the burning of cow dung seems bound to continue, but it is clear that more of the manurial value could be made available for crop production if cattle were better fed and maintained on the holdings, wherever possible. 
Breeding practice and European cattle. Except among the expert breeders, who are dying out as the best of the grazing areas are taken up for arable cultivation, there is little tendency to ensure systematic mating to produce definite types, and one of the great dangers of importing European cattle into India is that the male cross-bred progeny are used indis. criminately as sires. It has now been shown that the better Indian breeds can easily be improved to a relatively high standard, by proper breeding, feeding and management. To control such work properly among the 200 million livestock of India, organized animal. husbandry is, however, essential; thus it would take the place of these professional breeders. Otherwise sires of mixed or unknown parentage will be more and more used, though it is now well known that their progeny is very inferior.

Buffalo or cow. Much more highly fed as it usually is, the she-buffalo is generally considered to be a much more efficient milk and butter-fat producer than the cow, but a careful analysis of available data has shown that this is probably the case only where an abundance of coarse grazing is available. Indeed, strictly assessed in relation to the relatively high value in nutrition of the solids-not-fat of milk and with due regard to the need for a correctly balanced diet for the people, it is probable that for home production the balance would favour cows of the best Indian milch breeds. Under parallel conditions of feeding and management, such cows produce as much or more milk than buffaloes, and although the percentage of butter-fat is lower, the Zebu cow is highly efficient in converting dry crop residues into food of high biological value, and can even produce butter-fat as cheaply as the buffalo. For commercial dairying the buffalo has obvious advantages, but it is difficult to feel that the custom of maintaining shebuffaloes for milk production as well as cows for the production of working bullocks can be economically sound in rural areas.

Calf-rearing. In the case of buffaloes, the female calves are usually well fed and reared, while most of the males are allowed to succumb. In the case of cows the opposite happens, and in both cases it is the custom to present the stuffed hides to the cows at milking time to induce them to give their milk. In recent years it has been shown, however, that with proper handling when first brought into the milking herd, Indian cows yield their milk perfectly well without this, and that early maturity can readily be induced. It seems, therefore, that on agricultural holdings it would be sounder to use cows and feed them and both the male and female calves properly, instead of maintaining buffaloes as domestic milk producers and cows to provide the essential supply of work cattle. The custom of keeping cows in cities should also be discouraged, since it is insanitary and the cows-usually the best obtainable-are generally slaughtered at the end of the current lactation.

Dual- or single-purpose cattle. Judging from the limited success which expert breeders have obtained in Great Britain in their endeavours to produce cattle which are really efficient dual-purpose animals, for the production of milk and meat, it would probably be extremely difficult to produce breeds which would be efficient both for milk production and for the fast trotting or walking work which is the main purpose for which cattle are bred in India. With the rapid spread of motor transport the demand for fast trotting bullocks for road work is, moreover, rapidly decreasing, and with heavier ploughs it seems probable that slower moving cattle may in future be more acceptable to cultivators. A strong view is, however, held among them, from north to south of India, that capacity for fast work and high milk production do not go together. In any event, in view of the very striking improvement which has in recent years been effected in the milk yield, early maturity and docility of pure Indian dairy cattle, it seems certain that the best of these breeds will be developed to still higher levels. Milk recording and the publication of milk records has been undertaken by the Animal Husbandry Bureau to this end.

Annual droving of dealers' cattle. The droving of immense numbers of dealers' cattle from north to south and east to west of India involves constant danger of spreading contagious disease of all kinds, and protective inoculation of such cattle should so far as possible be enforced.

Animal husbandry departments. Embracing as it does about one third of the domesticated animals of the world, animal husbandry in India is obviously a huge undertaking, the development of which on modern lines requires much more extensive Govern. ment provision, independent of the requirements of cash crops, than has so far been made available.

It is not possible in the limited space at my dis. posal to discuss all the measures which were taken during my eight years as animal husbandry expert to place the various branches of animal husbandry in India on a better footing. From the first it was obvious that in view of the crippling losses from disease, malnutrition and similar causes, far more comprehensive Government expert assistance to stock owners was required. Every help was accordingly given by the Imperial Council of Agricultural Research to the reorganization of the Mukteswar Research Institute as (1) a research station in the hills, with staff and facilities for dealing in appropriate sections with all branches of veterinary re. search, and (2) a plains station for the production of biological products on the very large scale which is needed, and for research which can be satisfactorily carried out in the plains. The research staff at Mukteswar was organized in appropriate sections, each capable of dealing with a branch of veterinary research, and the substation at Izatnagar was provided with additional sections to deal with animal nutrition, poultry and poultry diseases, and genetics, in addition to the production of biological pro. ducts. In this way a very comprehensive animal husbandry research and production institute was built up, and to provide the necessary link between research and the field work of Provincial veterinary departments, a veterinary investigation officer was also provided by the Imperial Council of Agricultural Ressearch for each British Province and certain affiliated Indian States. These have been found of great value both to research and in the systematic study of local disease problems, and have now been made a permanent part of Provincial and State disease control organizations. Stockmen, capable of carrying out inoculation and first-aid treatment, after suitable training at veterinary hospitals, were also arranged for. The facilities for disease control and animal husbandry have thus been improved and research plans facilitated both at Mukteswar and at veterinary colleges, and during the past decade our knowledge of disease conditions and of the incidence of disease has been greatly increased. 
The standard of veterinary education and technical training was improved at most veterinary colleges, and arrangements have recently been made to institute a B.Sc. university degree course at the Madras Veterinary College, in conjunction with the four-year veterinary graduates course. This is a welcome move in the direction of higher veterinary education, which is much needed in India.

Much attention was given to the improvement of dairying in India; this topic has been dealt with exhaustively by Dr. Norman Wright, who was brought out to give expert advice on the many and difficult problems which have to be faced by this industry under Indian conditions. Attention was also given to the control of disease among equines and to the improvement of local breeds of horses and donkeys; the breeding of horses was in the main provided for by a military organization, in the operations of which the Imperial Council of Agricultural Rosearch had no say.

The nucleus of an Animal Husbandry Bureau was also formed and all the information available in the records of military dairies, dairy farms and similar institutions was extracted and published. By this means the great potentialities of pure-bred Indian cattle in regard to milk production was for the first time made generally known, and in combination with the publication of milk records, has acted as a great stimulus to the improvement of pure Indian milch breeds.

Authoritative definitions of the breed characteristics of several of the best-known breeds of Indian cattle were also taken up by the Bureau and have since been published; and a village survey was carried out, in four areas in different parts of India, with the view of ascertaining precisely the amount of milk and other dairy products produced and consumed by the Indian ryot.

A co-ordinated scheme for the improvement of the sheep of various parts of India was instituted by the Imperial Council of Agricultural Research, and a representative was sent to South Africa to obtain first-hand information with the view of considering the possibility of establishing an Angora goat industry in certain parts of India where similar goats already existed. Some assistance was also given to the improvement of village goats and poultry.

The main problem of animal husbandry in India is the improvement of the working bullock, and one of the most important measures taken to improve livestock was the organization in 1938 of the first All-India Cattle Show at New Delhi, at which representatives of the most important breeds of pure Indian Zebu cattle were exhibited for the first time in history. Such a central show is a logical develop. ment of the annual shows which are held in many Provinces and States, and at which local cattle are judged and prizes given, each year. These shows are a part of the measures taken by Provincial Govern. ments to secure systematic improvement of livestock and have proved of the greatest value in suitable areas. If properly followed up, the central show should serve to advertise to the world that, for tropical countries, Indian Zebu cattle have no equals.

As it covers no less than about one third of the domesticated animals of the world, animal husbandry in India obviously requires much more extensive Government provision, apart altogether from the requirements of cash crops.

\section{X-RAY ANALYSIS OF HAMOGLOBIN}

\author{
By M. F. PERUTZ
}

Cavendish Laboratory and Molteno Institute, Cambridge

T $T$ has been shown that very detailed X-ray diffraction photographs can be obtained from crystals of horse methæmoglobin suspended in concentrated solutions of ammonium sulphate. On rapid drying in air, these crystals contract by 42 per cent of their wet volume. The dried crystals give a poor diffrac. tion pattern consisting of few low-order reflexions around the central spot ${ }^{1}$.

A method has now been developed whereby it is hoped greatly to extend the information which X-ray photographs from single crystals of proteins have yielded up to the present. It is based upon a sug. gestion first put forward by Bernal, who observed that after the transition of chymotrypsin crystals from the wet to the air-dried state, the shrinkage is accompanied by alterations of the relative intensities of reflexions. Bernal concluded that if it were possible to obtain complete sets of reflexions in different states of hydration of the crystal, then this may enable us to distinguish between the effects of intra- and inter-molecular scattering and, eventually, to compute a direct Fourier synthesis of the molecular structure of the protein ${ }^{1}$.

Single crystals of horse methæmoglobin can be made to contract so slowly that the complete drying process occupies several days. In addition, it was found possible to arrest the contraction over periods of weeks at stages of hydration intermediate between the wet and the air-dried, leaving sufficient time at each stage to record the reflexions from the principal crystal zones. So far the following results have been obtained :

(a) Cell dimensions and optical properties. Horse methæmoglobin crystals are monoclinic and belong to the space group $C 2$, with two molecules in the unit cell. The cell dimensions at various degrees of contraction are given in the accompanying table. It

Cell Dimensions at Different Stages of Shrinkage

\begin{tabular}{|c|c|c|c|c|c|c|c|}
\hline $\begin{array}{l}\text { Stage of } \\
\text { shrinkage }\end{array}$ & $a$ & $b$ & $c$ & $\beta$ & $c \sin \beta$ & $\begin{array}{l}\text { Volume } \\
\left(\mathbf{A} .^{8}\right)\end{array}$ & $\begin{array}{c}\text { Con- } \\
\text { traction } \\
\text { per cent }\end{array}$ \\
\hline 1 Wet. & 109 & $63 \cdot 8$ & $55 \cdot 1$ & $111 \cdot 1$ & $51 \cdot 4$ & 357,000 & - \\
\hline 2 Inter- & $\begin{array}{c} \pm 0 \cdot 5 \\
, "\end{array}$ & " & $51 \cdot 4$ & $116 \cdot 2$ & $46 \cdot 1$ & 321,000 & $10 \cdot 3$ \\
\hline $3^{\text {mediate }}$ & "' & ," & 53.5 & 127.5 & $42 \cdot 3$ & 294,000 & $17 \cdot 7$ \\
\hline 4 Air- dried & $\begin{array}{r}104 \\
\pm 1.5\end{array}$ & ,' & $\begin{array}{c} \pm 0 \cdot 3 \\
54 \cdot 1 \\
\pm 1 \cdot 0\end{array}$ & $\begin{array}{l} \pm 0.5 \\
137.5 \\
\pm 1^{\circ}\end{array}$ & $\begin{array}{l}36.5 \\
\pm 0.5\end{array}$ & 242,000 & 32 \\
\hline
\end{tabular}

Probable errors are given wherever they exceed $0 \cdot 2 \mathrm{~A}$. or $0 \cdot 2^{\circ}$.

is seen that $b$ stays constant throughout the contraction, while $a$ does not change until the final stage 4, when it suddenly shrinks from $109 \mathrm{~A}$. to $104 \mathrm{~A}$. The most important variable is the $c$ spacing, which contracts by a total of 29 per cent. The angles between the optical extinction directions and the $a$ axis remain unchanged during the transition from stage 1 to stage 2. At stages 3 and 4 the crystals had become too opaque for optical examination.

(b) Changes of diffraction pattern. Shrinkage of the crystals has the effect of increasing the intensity of the diffuse background relative to that of the Bragg reflexions; it also causes the latter to fall 